\title{
PENGARUH JUMLAH JET HOLE DAN DIAMETER INNER PIPE TERHADAP UNJUK KERJA KOMPOR ALKOHOL
}

\author{
Irwan Humaidi, Ida Bagus Alit, I Made Nuarsa \\ Jurusan Teknik Mesin, Universitas Mataram
}

\begin{abstract}
Alcohol is an renewable alternative fuel produced from plants material. Plants usually contains essence such as : cassava, yam, corn, and sago palm essence. Processing for producing alcohol begin from hydrolysis process, that is essence converts to glucose then fermentation process to converting glucose to ethanol and $\mathrm{CO}_{2}$. After fermentation process ends, we continue to destilation process to decomposing alcohol based on its boiling point.

This research aims to know design of alcohol stove design by variating its jet hole quantity and inner pipe diameters. Duration of heating, heat dropped, fuel consumption, and alcohol-stove efficiency are attentioned variables in this research. Combustion process of alcohol-stove begin with entering fuel to fuel tube then firing up the stove by striking fire on weep hole in inner pipe, combustion will increasing stove temperature and steam the alcohol. The steam will turn out through the jet hole so the stove flame is stable.

This research result shows have been showing the stove most optimum showed by alcohol stove with $1 \frac{1}{2}$ inch inner pipe diameter variation with most jet hole is 8 holes, because the efficience at variation of this stove is high and the burning time it quick also. The greatest quantity of fuel consumption with variety of jet hole 16 amount with $11 / 2$ inch diameter that is $0.1061 \mathrm{ml} / \mathrm{second}$. Whereas the bigest stove efficiency contained in stove with inner pipe diameter variety $1 \frac{1 / 4}{4}$ inch with amount of jet hole 8 that is $48,33 \%$.
\end{abstract}

Keywords : jet hole, inner pipe, alternative energy, alcohol-stove, efficiency

\section{Pendahuluan}

\subsection{Latar Belakang}

Alkohol sejak dulu sudah mulai dikembangkan oleh bangsa Romawi, mereka menggunakan alkohol untuk bahan bakar lampu penerangan rumah-rumah bangsawan. Sekarang penggunaan alkohol sangat luas dimasyarakat terutama untuk keperluan darurat maupun praktis, diantaranya yaitu: mensterilkan peralatan kedokteran, pemanas makanan dipanci/nampan catering, atau dipergunakan pada saat camping/kemah, juga di medan perang, karena memang penggunaan sangat praktis, tidak berbau, mudah dibawa dan dipindahkan, namun mempunyai kelemahan, lidah apinya tidak bisa memancar seperti kompor gas, sehingga panas yang dihasilkan kurang bagus.(anonim,2010).

Alkohol/bioetanol merupakan salah satu bahan bakar alternatif terbarukan.

Meningkatkan pengunaan bahan bakar alkohol dimasyarakat akan mengurangi pengunaan bahan bakar fosil yang semakin lama harganya semakin meningkat. Apalagi kebijakan pemerintah mengurangi subsidi minyak tanah akan berdampak pada masyarakat yang biasa mengunakan bahan bakar minyak tanah. Masyarakat akan terpaksa beralih mengunakan bahan bakar gas LPG, akan tetapi masih banyak masyarakat yang ketakutan menggunakan bahan bakar gas disebabkan oleh berita yang mengabarkan bahan bakar gas LPG $3 \mathrm{~kg}$ sering meledak, sehingga masyarakat resah dan takut mengunakan bahan bakar gas.

Untuk meningkatkan pengunaan bahan bakar alkohol/bioetanol sebagai bahan bakar alternatif dimasyarakat. Harus diciptakan kompor alkohol yang sederhana, murah, dan mudah dibuat dengan hasil pembakaran yang maksimal. Dalam memaksimalkan hasil pembakaran tidak terlepas dari desain ruang bakar yang baik, karena ruang bakar yang baik dapat mensirkulasikan kalor secara tepat sehingga dapat mengurangi kalor yang terbuang.

\subsection{Tujuan Penelitian}

Adapun tujuan penelitian ini adalah:

untuk mengetahui pengaruh variasi diameter dalam(inner pipe) dan jumlah lubang keluar bahan bakar(jet hole) terhadap unjuk kerja kompor alkohol.

\section{Teori}

2.1 Kompor Alkohol 


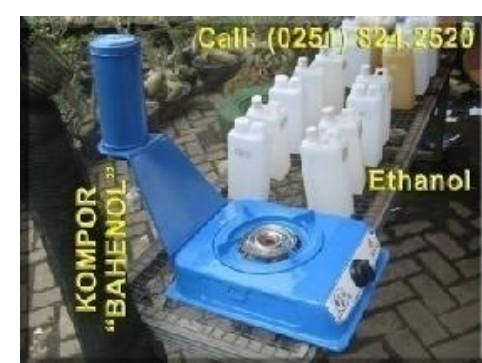

Gambar 2.1 kompor bahenol

Kompor "BAHENOL" adalah kompor alkohol yang hemat bahan bakar, unik dan mudah pemakaiannya. Dalam pemakaian seharihari untuk tingkat keamanannya cukup baik, tidak seperti kompor minyak tanah atau tabung gas $3 \mathrm{~kg}$ yang bisa-bisa meledak dan menyebabkan kebakaran. Hanya saja, kompor ini harus diletakan jauh dari tempat pembakaran sampah atau dari api yang sedang menyala, karena sifat dan oktan alkohol yang sangat tinggi dan mudah terbakar.

Kompor ini menggunakan bahan bakar berupa alkohol dengan kadar $60 \%$ $70 \%$. Pemakaian kompor "BAHENOL ini tidak seperti pemakaian kompor yang masih menggunakan minyak tanah atau kayu bakar. Jika wadah diletakan di atas tungku, maka wadah yang menggunakan kompor minyak tanah akan berjelaga, hitam, kotor, dan ruangan penuh dengan asap dan bau yang menyengat. Sedangkan kompor "BAHENOL" tidak membuat jelaga, asap, bau yang menyengat, dan api yang dihasilkan biru dengan panas yang tinggi.(anonim,2012)

\subsection{Alkohol Dan Proses Pembuatannya}

Alkohol merupakan suatu senyawa organik yang tersusun dari atom $\mathrm{C}, \mathrm{H}$ dan $\mathrm{O}$ dengan rumus umum $\mathrm{C}_{n} \mathrm{H}_{2 n+1} \mathrm{OH}$. Ciri khas alkohol yaitu terdapatnya gugus $-\mathrm{OH}$ pada rantai karbon. Dilihat dari gugus fungsinya ini, alkohol memiliki banyak golongan. Golongan yang paling sederhana adalah metanol dan etanol.

Proses pengolahan bioetanol diawali dengan proses hidrolisis, yaitu proses konversi pati menjadi glukosa kemudian dilanjutkan dengan proses fermentasi untuk mengkonversi glukosa (gula) menjadi etanol dan $\mathrm{CO}_{2}$, dimana fermentasi etanol adalah perubahan $1 \mathrm{~mol}$ gula menjadi $2 \mathrm{~mol}$ etanol dan $2 \mathrm{~mol} \mathrm{CO}_{2}$. Setelah itu dilakukan proses destilasi untuk memisahkan etanol, dimana distilasi merupakan pemisahan komponen berdasarkan titik didihnya. (Musanif,2012)

\subsection{Pembakaran}

Pembakaran adalah reaksi kimia yang cepat antara oksigen dan bahan bakar disertai dengan konversi energi kalor dalam jumlah yang besar. Pembakaran sempurna (complete combustion), terjadi jika semua unsur $\mathrm{C}, \mathrm{H}$ dan $\mathrm{S}$ yang terkandung dalam bahan bakar bereaksi membentuk $\mathrm{CO}_{2}, \mathrm{H}_{2} \mathrm{O}$ dan $\mathrm{SO}_{2}$. Pembakaran sempurna dapat dicapai dengan : pencampuran antara bahan bakar dan oksidator dengan tepat dan baik, yaitu perbandingan rasio bahan bakar per udara tepat. Pembakaran tidak sempurna ( incomplete combustion), terjadi jika proses pembakaran bahan bakar menghasilkan "intermediate combustion product' seperti $\mathrm{CO}, \mathrm{H}_{2}$, aldehid, disamping $\mathrm{CO}_{2}$ dan $\mathrm{H}_{2} \mathrm{O}$. Pembakaran tidak sempurna dapat terjadi antara lain karena pasokan oksidatornya terbatas atau kurang dari jumlah yang diperlukan. Pembakaran spontan (spontaneous combustion), terjadi jika zat atau bahan mengalami oksidasi perlahan-lahan, kalor yang dihasilkan tidak dilepas, sehingga suhu bahan bakar naik secara perlahan mencapai titik bakarnya (ignition point), maka bahan terbakar akan menyala dengan sendirinya.

\subsection{Bahan Bakar Cair}

\section{Minyak bumi}

Minyak bumi didapat dari tambang minyak dengan cara mengebornya diladang-ladang minyak dan memompanya sampai ke atas permukaan bumi. Untuk selanjutnya diolah lebih lanjut menjadi berbagai jenis minyak bakar. Minyak bumi (crude oil) yang berwarna coklat tua sampai kehitaman terdiri dari campuran berbagai macam persenyawaan zat cair arang ( $\mathrm{C}$ dan H). Minyak bumi adalah campuran komplek hidrokarbon plus senyawaan organik dari Sulfur, Oksigen, Nitrogen dan senyawasenyawa yang mengandung konstituen logam terutama nikel, besi dan tembaga. unsur-unsur yang terdapat dalam minyak bumi sangat bervariasi.

\section{Methanol}

Salah satu jenis bahan bakar cair yang akhir-akhir ini mulai dilirik untuk dijadikan sebagai bahan bakar dalam skala kecil maupun menengah adalah Methanol. Methanol juga dikenal sebagai methil alkohol, wood alkohol atau spiritus, adalah senyawa kimia dengan rumus kimia $\mathrm{CH}_{3} \mathrm{OH}$. la merupakan bentuk alkohol paling sederhana. Pada keadaan atmosfer ia 
berbentuk cairan yang ringan, mudah menguap, tidak berwarna, mudah terbakar, dan dengan bau yang khas. Digunakan sebagai bahan pendingin anti beku, pelarut, bahan bakar dan sebagai bahan addiktif bagi ethanol industri.

\section{Ethanol}

Ethanol disebut juga etil alkohol, alkohol murni, alkohol absolut atau alkohol saja adalah sejenis cairan yang mudah menguap, mudah terbakar, tak berwarna dan merupakan alkohol yang paling sering digunakan dalam kehidupan sehari-hari. Ethanol termasuk dalam alkohol rantai tunggal dengan rumus kimia $\mathrm{C}_{2} \mathrm{H}_{5} \mathrm{OH}$.

Fermentasi gula menjadi ethanol merupakan salah satu reaksi organik paling awal yang pernah dilakukan manusia. Pada zaman modern ethanol yang ditujukan untuk kegunaan industri dihasilkan dari produk sampingan pengilangan minyak. Senyawa ini merupakan obat psikoaktif dan dapat ditemukan pada minuman beralkohol dan termometer modern.

\subsection{Kalor Pembakaran}

Istilah kalor pertama kali diperkenalkan oleh Antoine Laurent Lavoisier (1743-1794). Menurutnya, kalor merupakan zat yang berpindah dari suatu benda ke benda yang lain karena adanya perbedaan temperatur diantara kedua benda tersebut. Satuan kalor pada masa itu disebut satuan kalori. Jika suatu benda menerima/melepaskan kalor maka suhu benda itu akan naik/turun atau wujud benda berubah :

Kapasitas suatu zat didefinisikan sebagai jumlah kalor yang dibutuhkan oleh zat untuk menaikkan suhunya satu derajat. Energi kalor sering kita gunakan dalam kehidupan sehari-hari, misalnya untuk memasak air kita menggunakan energi kalor dari api, mengubah wujud es batu menjadi air dengan cara memanaskan-nya (memberi energi kalor). Energi kalor dapat dihitung dengan rumus matematika sebagai berikut:

$Q=m \cdot c \cdot \Delta t$

Dimana:

$\mathrm{Q}=$ Kalor yang diterima suatu zat $(\mathrm{kJ})$

$\mathrm{m}=$ Massa zat (Kilogram)

$\mathrm{C}=$ Kalor jenis $\left(\mathrm{kJ} / \mathrm{kg}^{\circ} \mathrm{C}\right)$

$\Delta \mathrm{t}=$ Perubahan suhu $\left({ }^{\circ} \mathrm{C}\right) \rightarrow\left(\mathrm{t}_{2}-\mathrm{t}_{1}\right)$

\subsection{Konsumsi Bahan Bakar}

Konsumsi bahan bakar merupakan ukuran pemakaian bahan bakar. Biasanya diukur dalam satuan volume pengunaan bahan bakar per satuan waktu, atau bisa didefinisikan sebagai jumlah bahan bakar yang digunakan selama waktu tertentu, satuan yang digunakan biasaya liter per jam.

Besarnya komsumsi bahan bakar (Fuel Consumption) dapat dihitung dengan persamaan

$$
F C=\frac{\text { volume bahan bakar }}{\text { wakt }}\left(\frac{\text { liter }}{\text { jam }}\right)
$$

\section{Metode Penelitian}

\subsection{Disain Kompor Alkohol}

Adapun disain kompor yang akan digunakan dapat dilihat pada gambar dibawah ini.

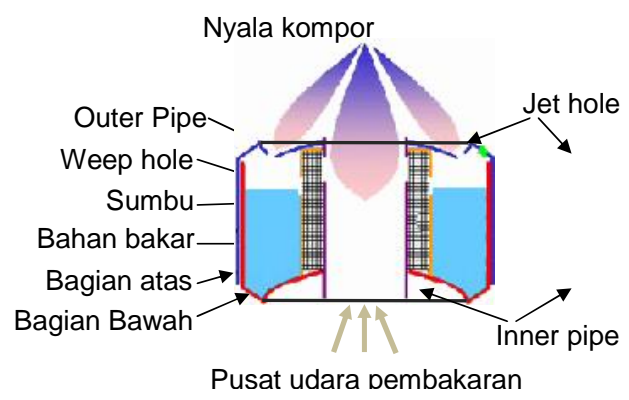

Gambar 3.1 Disain kompor alkohol

Keterangan :

1. Jet hole ialah lubang keluaran gas hasil penguapan bahan bakar.

2. Weep hole ialah lubang bahan bakar melewati sumbu.

3. Inner pipe ialah pipa dalam sebagai jalur udara pembakaran.

4. Outer pipe ialah pipa luar dimana fungsinya untuk pembatas sumbu dan ruang bahan bakar.

\subsection{Pembuatan Alat}

Adapun langkah-langkah dalam pembuatannya sebagai berikut:

1. Potong pipa sebagai inner pipe dengan diameter 1", $1_{1 / 4}$ "dan $1_{1 / 2}$ " sepanjang $40 \mathrm{~mm}$.

2. Buat lubang pada sekeliling inner pipe sebanyak 8 buah dengan pusat lubang berjarak $10 \mathrm{~mm}$ dari ujung pipa dengan diameter $6 \mathrm{~mm}$.

3. Potong pipa/kaleng sebagai outer pipe sepanjang $40 \mathrm{~mm}$ dan buat lubang 4 buah pada sekeliling outer pipe. 
4. $\quad$ Potong 2 buah kaleng minuman yang kapasitas $330 \mathrm{ml}$ setinggi $35 \mathrm{~mm}$ dari bagian bawah.

5. Buat lubang sebesar diameter inner pipe pada 2 buah kaleng tersebut.

6. Untuk bagian atas buatkan lubang jet hole dengan diameter sebesar $1 \mathrm{~mm}$ sebanyak perlakuan yaitu 8,12 dan 16 buah.

7. Buatkan lubang masuk bahan bakar.

8. Untuk bagian bawah disatukan dengan inner pipe dan diberikan perekat supaya tidak bocor.

9. Kelilingi inner pipe dengan sumbu dan tutup dengan outer pipe.

10. Satukan bagian atas dan bawah dan buatkan penutup lubang bahan bakar

11. Lakukan prosedur 1-10 untuk pembutan kompor selanjutnya.

\subsection{Prosedur Penelitian}

Sebelum dilakukannya prosedur penelitian ini, sudah dilakukan pengujian pendahuluan untuk mendapatkan berapa liter air yang digunakan agar tidak mendidih.

Adapun prosedur pengujian untuk energi yang dilepaskan sebagai berikut:

1. Masukkan bahan bakar sebanyak 30 $\mathrm{ml}$ ke dalam kompor

2. Nyalakan kompor alkohol tersebut

3. Masukkan air sebanyak 1 liter ke dalam panci dan naikkan di atas kompor

4. Catat waktu pemanasan setiap kenaikan satu temperatur sampai bahan bakar habis.

5. Lakukan prosedur 1-5 sebanyak tiga kali pengulangan.

6. Lakukan prosedur 1-6 pada pengujian kompor selanjutnya.

\section{Hasil Dan Pembahasan}

Hasil pengujian pada penelitian ini diperoleh berdasarkan prosedur yang telah ditetapkan dalam metode penelitian.

\subsection{Hubungan Antara Waktu Pemanasan Dengan Temperatur}

Dari hasil pengujian pada kompor alkohol dengan variasi jumlah jet hole $(8,12,16)$, diameter inner pipe $\left(1 ", 1_{1 / 4}, 1_{1 / 2}\right)$ dan kompor tanpa perlakuan, untuk memanaskan air 1 liter dengan bahan bakar metanol $100 \%$ sebanyak $30 \mathrm{ml}$. dapat di lihat pada grafik 4.1 berikut:

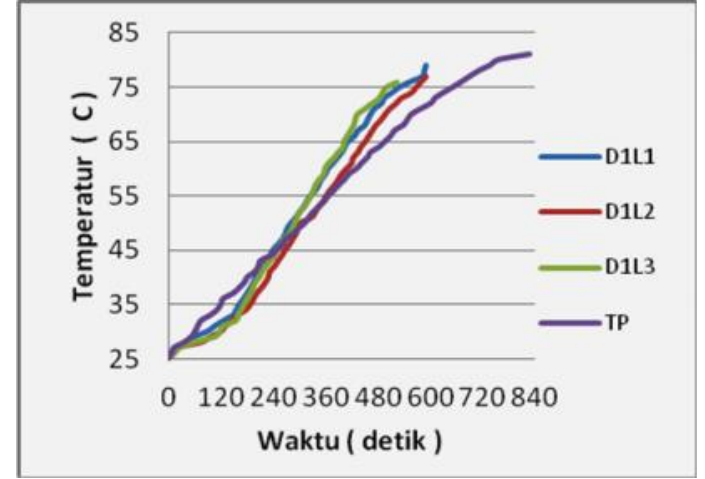

Gambar 4.1 Hubungan AntaraWaktu Dan Temperatur Pada Variasi Jumlah Jet Hole 8buah, 12 buah, 16 buah Dengan Diameter Inner Pipe 1 Inchi

Dari gambar 4.1 dapat dilihat bahwa semakin banyak jumlah jet hole temperatur yang dihasilkan turun, akan tetapi waktu.

Untuk memanaskan air semakin cepat. Hal ini disebabkan karena semakin banyak jumlah jet hole akan mempengaruhi jumlah bahan bakar yang keluar sehingga waktu yang dibutuhkan lebih cepat untuk menghabiskan bahan bakar dengan jumlah yang sama.

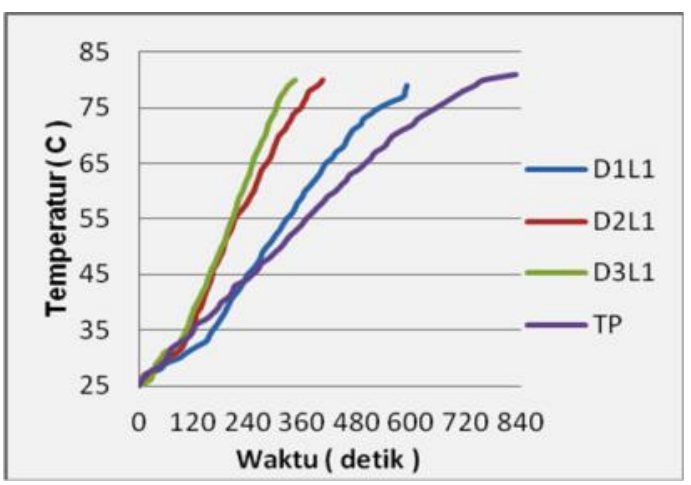

Gambar 4.2 Hubungan AntaraWaktu Dan Temperatur PadaVariasi Diameter Inner Pipe 1", 1 1/4 "dan $1 \frac{1}{2} 2$ "Dengan Jumlah Jet Hole 8.

Dari gambar 4.2 juga dapat dilihat bahwa semakin besar diameter inner pipe maka waktu yang dibutuhkan memanaskan air semakin singkat. Hal ini dapat dijelaskan bahwa semakin besar diameter inner pipe akan mempengaruhi udara pembakaran dan dimensi kompor yang berdampak terhadap distribusi kalor pada kompor lebih cepat sehingga bahan bakar yang keluar melewati jet hole lebih cepat yang menyebabkan waktu pemanasan semakin singkat. 


\subsection{Pengaruh Jumlah Jet Hole Dan Diameter Inner Pipe Terhadap Kalor Yang Diserap \\ Dari data pengujian yang dilakukan} pada kompor alkohol dengan variasi jumlah jet hole dan diameter inner pipe didapatkan

$\mathrm{t}$ dari selisih antara temperatur akhir dan temperatur awal. Dan dapat dihitung berapa kalor yang mampu diserap oleh air 1 liter dengan mengunakan bahan bakar sebanyak $30 \mathrm{ml}$, dengan rumus matematikanya sebagai berikut :

$Q=m \cdot c \cdot \Delta t$

$\mathrm{Q}=$ Kalor yang diterima suatu zat $(\mathrm{kJ})$

$\mathrm{m}=$ Massa zat $(\mathrm{kJ})$

$\mathrm{C}=$ Kalor jenis $\left(\mathrm{kJ} / \mathrm{kg}^{\circ} \mathrm{C}\right)$

$\Delta \mathrm{t}=$ Perubahan suhu $\left({ }^{\circ} \mathrm{C}\right) \rightarrow\left(\mathrm{t}_{2}-\mathrm{t}_{1}\right)$

Sebagai contoh perhitungan diambil data pada tabel lampiran 1 ( data pegujian ), untuk jumlah jet hole 8 buah dan diameter inner pipe 1 inchi dimana temperatur awal $25{ }^{\circ} \mathrm{C}$ dan temperatur akhir $80^{\circ} \mathrm{C}$, didapat kan $t$ sebesar $55^{\circ} \mathrm{C}$. Sedangkan massa air didapatkan dari perhitungan:

$$
\begin{aligned}
\mathrm{m} & =\rho \cdot \mathrm{V}_{\text {air }} \\
& =997 \mathrm{~kg} / \mathrm{m}^{3} \cdot 0,001 \mathrm{~m}^{3} \\
& =0,997 \mathrm{~kg}
\end{aligned}
$$

Maka nilai kalor dapat dihitung sebagai berikut:

$$
\begin{aligned}
& Q=m \cdot c \cdot \Delta t \\
& Q=0,997 \mathrm{~kg} \cdot 4,18 \mathrm{~kJ} / \mathrm{kg} \cdot \mathrm{C} \times 55 \mathrm{C} \\
& \mathrm{Q}=299,21 \mathrm{~kJ}
\end{aligned}
$$

Dengan rumus matematika yang sama dilakukan perhitungan pada data yang ada, maka didapatkan hasil perhitungan kalor yang diserap rata- rata sebagai berikut:

Tabel 4.3 Rerata kalor yang diserap

Untuk lebih jelas data yang terdapat pada tabel 4.3 dapat dibuat dalam bentuk grafik yang ditunjukkan pada gambar 4.3 berikut:

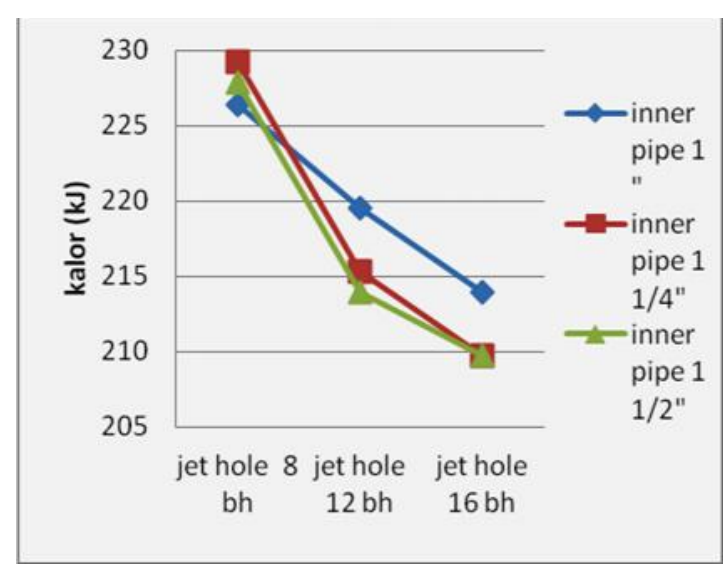

Gambar 4.3 grafik kalor yang diserap fungsi jumlah jet hole dan diameter inner pipe

Dari gambar 4.3 terlihat bahwa semakin banyak jumlah jet hole kalor yang diserap semakin kecil, hal ini disebabkan bahwa semakin banyak jumlah jet hole maka jumlah bahan bakar semakin banyak sedangkan udara pembakaran dari inner pipe sama sehingga ada bahan bakar yang tidak terbakar sempurna. Di samping itu banyak kalor yang terpapar ke lingkungan karena lidah api melibihi diameter panci. Hal ini dapat dilihat pada gambar 4.4 berikut:

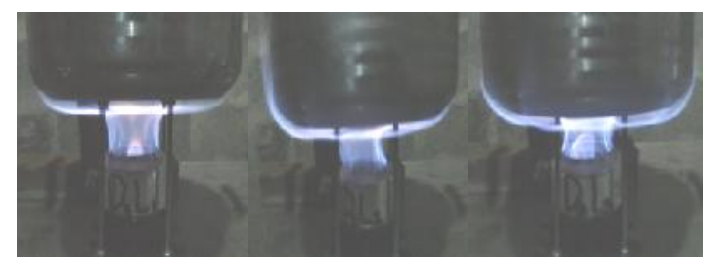

Gambar 4.4 kompor alkohol diameter inner pipe $1_{1 / 2}$ inchi dengan variasi jumlah jet hole 8 buah, 12 buah, 16 buah

\subsection{Pengaruh Jumlah Jet Hole Dan

\begin{tabular}{|c|c|c|c|}
\hline \multirow[b]{2}{*}{$\begin{array}{c}\text { Diamter } \\
\text { Inner } \\
\text { Pipe }\end{array}$} & \multicolumn{3}{|c|}{ Kalor $(\mathbf{k J})$} \\
\hline & $\begin{array}{c}\text { Jumlah } \\
\text { Jet Hole, } \\
\text { L1=8 }\end{array}$ & $\begin{array}{c}\text { Jumlah } \\
\text { Jet Hole, } \\
\text { L2 }=12\end{array}$ & $\begin{array}{c}\text { Jumlah } \\
\text { Jet Hole } \\
\text {,L3=16 }\end{array}$ \\
\hline $\begin{array}{l}\mathrm{D} 1=1 \\
\text { inchi }\end{array}$ & 226.43 & 219.49 & 213.93 \\
\hline $\begin{array}{l}\text { D2 = } 1_{1 / 4} \\
\text { inchi }\end{array}$ & 229.21 & 215.32 & 209.76 \\
\hline $\begin{array}{l}\text { D3 = } 11 \frac{1}{2} \\
\text { inchi }\end{array}$ & 227.82 & 213.93 & 209.76 \\
\hline
\end{tabular} Diameter Inner Pipe Terhadap Efisiensi Kompor Alkohol \\ Dari perhitungan kalor yang diserap} oleh 1 liter air dengan bahan bakar $30 \mathrm{ml}$, dapat dilakukan perhitungan untuk 
$\eta=\frac{\text { Qyang diserap }}{\text { Q ahtual }} \times 100 \%$

Dimana :

$\eta \quad=$ efisiensi kompor

$\mathrm{Q} \quad=$ kalor yang diserap oleh air

$\mathrm{Q}$ akt $=$ kalor hasil perhitungan

Sebagai contoh perhitungan diambil

data pada tabel lampiran 1 ( data hasil perhitungan kalor ), untuk jumlah jet hole 8 buah dan diameter inner pipe 1 inchi didapatkan nilai kalor yang diserap sebesar 229,21 kJ. Sebelum menghitung efisiensi kompor, awalnya mencari massa bahan bakar untuk mendapatkan nilai kalor aktul.

$$
\begin{aligned}
\mathrm{m} & =\rho \cdot \mathrm{V}_{\text {bahan bakar }} \\
& =787 \mathrm{~kg} / \mathrm{m}^{3} \cdot\left(30 \times 10^{-6}\right) \mathrm{m}^{3} \\
& =0,02361 \mathrm{~kg}
\end{aligned}
$$

Maka nilai kalor aktual didapatkan dari perhitungan:

$$
\begin{aligned}
Q \text { aktual } & =\text { NKB . masa bahan bakar } \\
& =20.089,6 \mathrm{~kJ} / \mathrm{Kg} \cdot 0,02361 \mathrm{~kg} \\
& =474,27 \mathrm{~kJ}
\end{aligned}
$$

Sehingga dari data diatas dapat dihitung efisiensi dari kompor yaitu:

$$
\begin{aligned}
& \eta=\frac{\text { Q yang diserap }}{q \text { aktual }}, 100 \% \\
& \eta=\frac{229,21 K_{j}}{474,27 K_{j}} \cdot 100 \% \\
& \eta=48,33 \%
\end{aligned}
$$

Dari semua data hasil perhitungan kalor yang diserap pada kompor alkohol dengan variasi jumlah jet hole dan diameter inner pipe dilakukan perhitungan efisiensi dengan cara yang sama, sehingga didapatkan hasil rata - rata efisiensi kompor sebagai berikut:

Tabel 4.5 Rerata efisiensi kompor

Untuk lebih jelas data yang terdapat pada tabel 4.4 dapat dibuat dalam bentuk grafik yang ditunjukkan pada gambar 4.5 berikut:

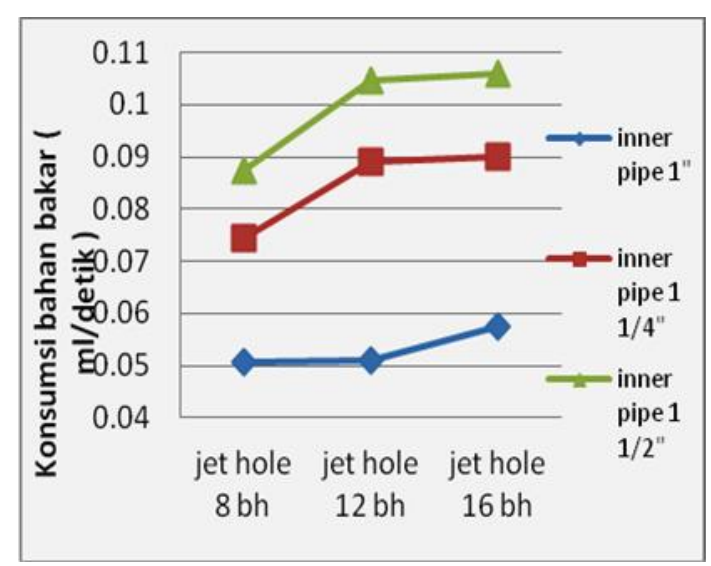

Gambar 4.5 grafik efisiensi kompor alkohol fungsi jumlah jet hole dan diameter inner pipe

Dari gambar 4.5 terlihat bahwa semakin banyak jumlah jet hole efisiensi semakin turun. Hal ini dapat dijelaskan bahwa efisiensi pada kompor alkohol dipengaruhi oleh kalor yang diserap oleh 1 liter air dengan bahan bakar yang sama.

\subsection{Pengaruh Jumlah Jet Hole Dan Diameter Inner Pipe Terhadap Konsumsi Bahan Bakar \\ Konsumsi bahan bakar (fuel consumption) merupakan ukuran} pemakaian bahan bakar pada suatu peroses pembakaran. Besarnya konsumsi bahan bakar dapat dihitung dengan rumus matematika sebagai berikut :

$$
F C=\frac{\text { volume bahan bakar }}{\text { waktu }}
$$

Dari data hasil pengujian didapatkan lama waktu pemanasan untuk menghabiskan bahan bakar sebanyak $30 \mathrm{ml}$. Dimana sebagai contoh perhitungan diambil data dari tabel lampiran 1 (data pengujian), pada kompor alkohol variasi diameter inner pipe 1 inchi dengan jumlah jet hole 8 buah. Rata -rata lama waktu pemanasannya 598 detik dengan bahan bakar $30 \mathrm{ml}$, maka laju konsumsi bahan bakarnya ialah

\begin{tabular}{|l|c|c|c|}
\hline \multirow{2}{*}{$\begin{array}{c}\text { Diameter } \\
\text { Inner Pipe }\end{array}$} & \multicolumn{3}{|c|}{$\begin{array}{c}\text { Konsumsi bahan bakar } \\
\text { (ml/detik) }\end{array}$} \\
\cline { 2 - 4 } & $\begin{array}{c}\text { Jumlah } \\
\text { Jet Hole } \\
\text { L1=8 }\end{array}$ & $\begin{array}{c}\text { Jumlah } \\
\text { Jet Hole } \\
\text { L2=12 }\end{array}$ & $\begin{array}{c}\text { Jumlah } \\
\text { Jet Hole } \\
\text { L3=16 }\end{array}$ \\
\hline D1 =1“ & 0.0508 & 0.0509 & 0.0575 \\
\hline D2 =1 1/4" & 0.0744 & 0.0889 & 0.0900 \\
\hline D3 =1 1/2" & 0.0875 & 0.1048 & 0.1061 \\
\hline
\end{tabular}




$$
\begin{aligned}
& F C=\frac{\text { volume bahan bakar }}{\text { waktu }} \\
& F C=\frac{30 \mathrm{ml}}{598 \text { detik }} \\
& F C=0,0502 \mathrm{ml} / \text { detik }
\end{aligned}
$$

Dari semua data lama waktu pemanasan pada kompor dengan variasi jumlah jet hole dan diameter inner pipe dilakukan perhitungan dengan cara yang sama, sehingga didapatkan hasil rata-rata konsumsi bahan bakar sebagai berikut:

\begin{tabular}{|l|c|c|c|}
\hline \multirow{2}{*}{$\begin{array}{c}\text { Diameter } \\
\text { Inner Pipe }\end{array}$} & \multicolumn{3}{|c|}{ Efisiensi (\%) } \\
\cline { 2 - 4 } & $\begin{array}{c}\text { Jumlah } \\
\text { Jet hole } \\
\text { L1=8 }\end{array}$ & $\begin{array}{c}\text { Jumlah } \\
\text { Jet hole } \\
\text { L2=12 }\end{array}$ & $\begin{array}{l}\text { Jumlah } \\
\text { Jet hole } \\
\text { L3=16 }\end{array}$ \\
\hline D1 = 1“ & 47.74 & 46.28 & 45.11 \\
\hline D2 = 1 $1 /$ “ $^{\prime \prime}$ & 48.33 & 45.40 & 44.23 \\
\hline D3 =1 1/2" & 48.04 & 45.18 & 44.23 \\
\hline
\end{tabular}

Tabel 4.7 Rerata konsumsi bahan bakar

Untuk lebih jelasnya dapat dilihat pada gambar 4.6 yang didapat dari tabel 4.7

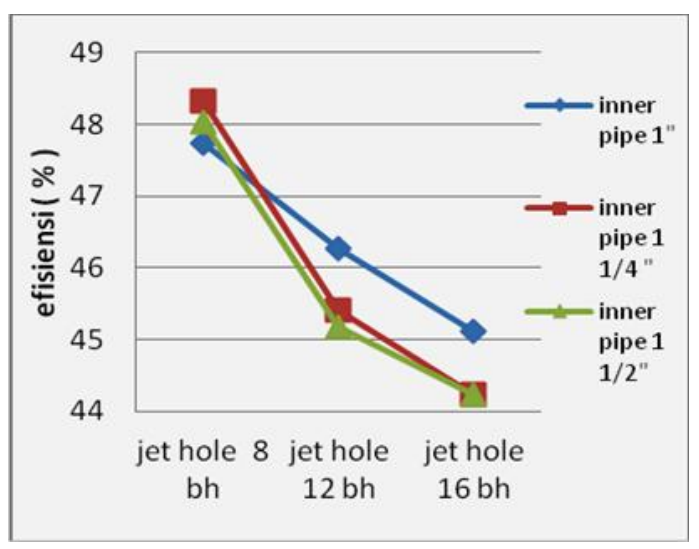

Gambar 4.6 grafik konsumsi bahan bakar fungsi jumlah jet hole dan diameter inner pipe

Dari gambar 4.6 dapat dilihat bahwa semakin banyak jumlah jet hole maka komsumsi bahan bakar per detik semakin tinggi, hal ini dapat dijelaskan bahwa semakin banyak jumlah jet hole maka jumlah bahan bakar yang keluar semakin banyak sehingga konsumsi bahan bakar per detik semakin banyak. Begitu juga semakin besar diameter inner pipe maka konsumsi bahan bakar semakin tinggi, hal ini dapat dijelaskan bahwa semakin besar diameter inner pipe akan mempenggaruhi dimensi kompor yang beribas pada distribusi kalor akan semakin cepat sehingga laju bahan bakar yang keluar melewati jet hole lebih cepat yang mengakibatkan konsumsi bahan bakar semakin banyak.

\section{Penutup}

\subsection{Kesimpulan}

Dari hasil penelitian dan

pembahasan yang telah dilakukan pada kompor alkohol dengan variasi jumlah jet hole dan diameter inner pipe dapat diambil beberapa kesimpulan sebagai berikut:

1. Kompor alkohol yang optimum di tunjukkan oleh kompor alkohol dengan variasi diameter inner pipe 11/2 inchi dengan jumlah jet hole 8 buah. Karena efisiensi pada variasi kompor ini tinggi dan waktu pembakaran juga cepat.

2. Variasi diameter inner pipe tidak berpengaruh terhadap kalor yang diserap dikarenakan kalor yang keluar melawati weep hole pada inner pipe digunakan untuk pemanasan awal dan bahan bakar lebih banyak keluar melewati jet hole.

3. Konsumsi bahan bakar yang paling banyak pada kompor dengan variasi jumlah jet hole 16 dengan diameter inner pipe $1 \frac{1}{2}$ inchi yaitu 0,1061 $\mathrm{ml} /$ detik dan konsumsi bahan bakar yang paling sedikit pada kompor dengan variasi jumlah jet hole 8 dengan diameter inner pipe 1 inchi yaitu $0,0508 \mathrm{ml} /$ detik.

4. Efisiensi kompor yang paling besar terdapat pada kompor dengan variasi diameter inner pipe $1_{1 / 4}$ inchi dengan jumlah jet hole 8 yaitu sebesar $48,33 \%$.

\subsection{Saran}

1. Perlu penelitian lebih lanjut mengenai pengaruh jumlah jet hole dan diameter inner pipe terhadap tinggi lidah api yang dihasilkan kompor alkohol.

2. Pada penelitian selanjutnya sebaiknya mengunakan panci yang diameternya lebih besar agar tidak terjadi kerugian kalor karena lebih banyak diserap ke lingkungan.

3. Sebelum melakukan penelitian sebaiknya memperhatikan suhu lingkungan.

4. Untuk mendapatkan kompor alkohol dengan efisiensi yang lebih bagus, sebaiknya disekeliling kompor diberikan penghalang untuk mengurangi panas yang keluar kelingkungan. 
Daftar Pustaka

Anonim. 2010 ,

Kompor

BoetanolSejarahnya,

http://komporbioetanol.wordpress.co $\mathrm{m} /$ 2010/02/24/kompor-bio-etanolsejarahnya/

Anonim.,2012, Energi Alternatif Bioetanol ,http//its-

online/energialternatif/bioethanol

Anonim., 2012, Kompor Bahenol, http://www.imagegambar.com/2012/ 03/kompor-bioethanol.html

Hidayat A.N.,2008, Pembuatan Alkohol Untuk

Bahan

bakar,http://empatyheart. wordpress.com/2008/06/30/62/

Kerampran, S., Desbordes, D., Veyssiere, B., 2000, Study of The Mechanisms of Flame Acceleratio in a Tube of Constant Cross Section, Combust. Sci and Tech, Vol. 158, pp 71-91.

Musanif Jamil., 2012,

Bioetanol,http://www.google.co.id/se arch?q=bioetanol+jamil+

musanif + fdf \&ie $=$ utf $-8 \& 0 e=u t f-$

$8 \& a q=t \& r l s=$ org $\cdot$ mozilla:en US:official\& client=firefox-a

Subroto., Aklis,Nur.,2011,Pengembangan Kompor Metanol Dengan Variasi Jumlah Lubang Burner Untuk Memperbaiki Karakteristik Pembakaran, Prosiding Simposium Nasional RAPI X ISSN:1412-9612 Fakultas Teknik Universitas Muhammadiyah Surakarta. hal M6 M12.

Prasetyo,Totok., Effendy,Marwan., 2003 , Formulasi Tinngi Nyala Bahan Bakar LPG Didaerah Stabilatas Nyala, Jurnal Teknik Gelagar, Vol 14 No 01, hal 73-79

Suwarjo Anton., 2012, Trangia OutdoorStove,http://antonarc01.mult iply.com/journal/ item/8/TrangiaOutdoor-StoveAwalnya-trangiadiciptakan-untuk-kebutuhan-sipil/ Jakarta.

\section{Lampiran}

Gambaran Proses Pembuatan Kompor

Alkohol

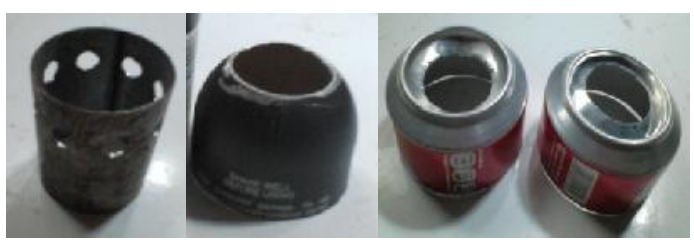

Inner pipe Outer pipe Bagian atas dan bawah

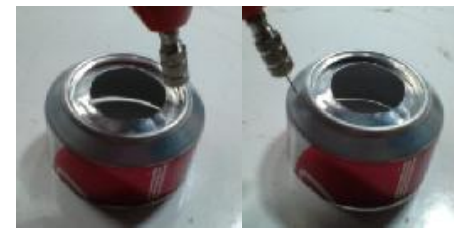

Pembuatan lubang bahan bakar

Pembuatan lubang jet hole

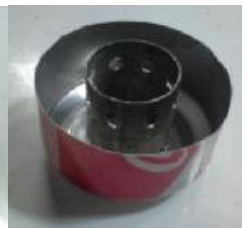

Gabungkan Inner pipe dan bagian bawah kompor

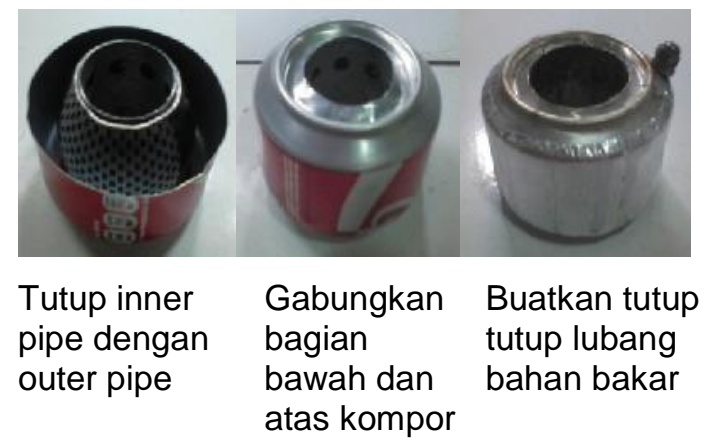

GAMBARAN PROSES PENGUJIAN
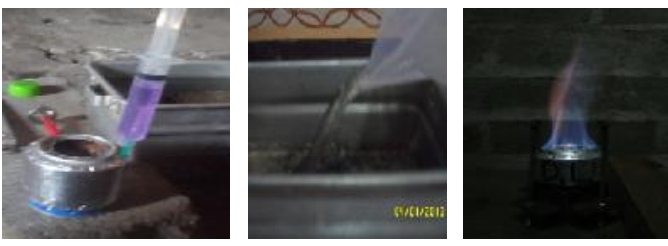

Masukkan Masukkan air Nyalakan Bahan bakar 1 liter

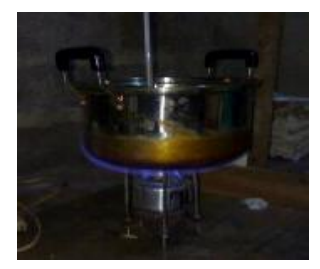

Naikkan di atas Kompor

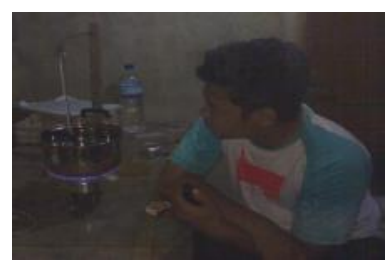

Catat waktu tiap kenaikan 1 derajat temperatur 